\title{
Fitness and physiology of Adelges tsugae (Hemiptera: Adelgidae) in relation to the health of the eastern hemlock
}

\author{
Anne C. Jones ${ }^{1}$, Donald E. Mullins ${ }^{2}$, Carlyle Brewster ${ }^{2}$, James P. Rhea ${ }^{3}$ and Scott M. Salom ${ }^{2}$ \\ ${ }^{1}$ Department of Entomology, Pennsylvania State University, PA 16801; ${ }^{2}$ Department of Entomology, Virginia Tech, Blacksburg, VA 24061 \\ and ${ }^{3}$ USDA Forest Service, Asheville, NC 28804-3454, USA
}

\begin{abstract}
The hemlock woolly adelgid, Adelges tsugae Annand is an invasive insect that frequently causes hemlock (Tsuga spp.) mortality in the eastern United States. Studies have shown that once healthy hemlocks become infested by the adelgid, nutrients are depleted from the tree, leading to both tree decline and a reduction of the adelgid population. Since A. tsugae is dependent on hemlock for nutrients, feeding on trees in poor health may affect the ability of the insect to obtain necessary nutrients and may consequently affect their physiological and population health. Trees were categorized as lightly or moderately impacted by $A$. tsugae based on quantitative and qualitative tree health measurements. Population health of $A$. tsugae on each tree was determined by measuring insect density and peak mean fecundity; A. tsugae physiological health was determined by measuring insect biomass, total carbon, carbohydrate, total nitrogen, and amino nitrogen levels. Adelges tsugae from moderately impacted trees exhibited significantly greater fecundity than from lightly impacted trees. However, A. tsugae from lightly impacted hemlocks contained significantly greater levels of carbohydrates, total nitrogen, and amino nitrogen. While the results of the physiological analysis generally support our hypothesis that $A$. tsugae on lightly impacted trees are healthier than those on moderately impacted trees, this was not reflected in the population health measurements. Adelges tsugae egg health in response to tree health should be verified. This study provides the first examination of $A$. tsugae physiological health in relation to standard $A$. tsugae population health measures on hemlocks of different health levels.
\end{abstract}

Key words Adelges tsugae; carbohydrates; fecundity; nitrogen; tree health; Tsuga canadensis

\section{Introduction}

The hemlock woolly adelgid, Adelges tsugae Annand (Hemiptera: Adelgidae) is a small invasive insect (1.3-1.5 mm long) native to Asia and western North America that has caused mortality to eastern and Carolina hemlock (Tsuga canadensis Carriere and $T$. caroliniana Engelmann, respectively) in urban and forest settings throughout eastern North America (Carter, 1971;

Correspondence: Anne C. Jones, Department of Entomology, Pennsylvania, PA 16801, USA. Tel: +1 814865 3088; email: acj152@psu.edu
McClure, 1987, 1989, 1991a; Cheah \& McClure, 2000). Eastern hemlock is particularly susceptible to this pest, since infested trees can survive from 4 to 10 years in declining health (McClure, 1991a; Eschtruth et al., 2013). In general, A. tsugae infestation causes hemlock needle loss, bud mortality, and a reduction of new growth (Eisenback et al., 2010). The presence of more than 3 A. tsugae per $20 \mathrm{~mm}^{2}$ of hemlock shoot is sufficient to inhibit new growth (McClure, 1991a; Stadler et al., 2005). Visible physical decline of the tree begins at $30 \%$ shoot infestation while $60 \%$ crown transparency marks the beginning of tree mortality (Mayer et al., 2002; Fidgen et al., 2006). 
Since native predators lack the specificity to impact $A$. tsugae populations, current management strategies focus on insecticide treatment, hemlock resistance, and biological control through natural enemy predators imported from western North America and Japan (Cowles et al., 2006; Joseph et al., 2011). Exotic beetles under consideration or released for biological control are Sasajiscymnus (= Pseudoscymnus) tsugae Sasaji and McClure, Scymnus spp. (Coccinellidae), Laricobius nigrinus Fender, and L. osakensis Shiyake and Montgomery (Derodontidae) (Havill et al., 2014).

The ecological and physiological processes that are essential for an organism's success have energetic costs that include acquisition of appropriate nutrients to support growth, survival, and reproductive fitness (Tomlinson et al., 2014). The nutritional resources (i.e., quality and micronutrient balance) provided by host plants can have a profound contribution to an insect's fitness (Lee, 2007). It is important to note that once $A$. tsugae immatures have selected a feeding site, their nutritional options are limited for obtaining appropriate nutrient materials for their development and reproduction. In addition, this adelgid must direct a considerable amount of its resources to both its physical and chemical defenses (Jones et al., 2014).

Plants provide all the nutrients herbivorous insects require, but available nutrient amounts may vary for herbivores based on environmental conditions of their host (Behmer, 2009). Stressed plants generally slow down cell growth, which in turn leads to investment in smaller plant structures, all of which will eventually impact insect performance (McClure, 1980; White, 1984; Larsson, 1989; Price, 1991; Cornelissen et al., 2008; Meloni et al., 2012). Initial feeding stress may cause increased nutrient mobilization away from the stressed area; however, this flow of nutrients will be depleted over time, and sap-feeding insect populations will decline (Cornelissen et al., 2008). Adelges tsugae may induce a type of phytotoxic response in hemlock that initially induces a more favorable nutritional state for the adelgid (Radville et al., 2011; Gómez et al., 2012). If populations are heavy enough, this response will eventually lead to reduced growth, decline in vigor, and eventual tree death (Miller-Pierce et al., 2010; Schwartzberg \& Montgomery, 2010; Radville et al., 2011). Because of its primarily sessile lifestyle, A. tsugae population is dependent on the health of the host tree. Similarly, hemlock health is affected by the herbivore's population size (McClure, 1991a).

Many studies have focused on the effect of $A$. tsugae on hemlock stands and associated ecosystems, yet few have examined the effect of hemlock health on A. tsugae population attributes and physiology (Jenkins, 1999;
Stadler et al., 2005; Stadler, 2006; Radville et al., 2011). Previous studies typically evaluated insect population density and fecundity during $A$. tsugae risk assessments on hemlock (McClure, 1991a; Broeckling \& Salom, 2003; Stadler et al., 2005; Lagalante et al., 2006). In this study, we hypothesize that less impacted hemlocks will host vigorous $A$. tsugae populations as exhibited by greater population density and peak mean fecundity of the sistens generation compared with less healthy trees. Since successful nutrient acquisition underlies insect survival, growth and reproduction, a suite of parameters (biomass, total carbon, nitrogen, carbohydrates, and amino nitrogen of the insect) were also examined as part of this hypothesis (Lee, 2007; Tomlinson et al., 2014).

\section{Materials and methods}

\section{Site selection}

Adelges tsugae instars and adults were collected from hemlocks at 3 locations (Virginia Tech College of Natural Resources and Environment, Fishburn Forest, Montgomery Co., VA, USA; University of Virginia Biological Station at Mt. Lake in Giles Co., VA, USA; and Twin Falls State Park, Wyoming Co., WV, USA) during the 20112012 field season. Due to the lack of $A$. tsugae populations and foliage at the Fishburn location, this site was excluded during the 2012-2013 field season. Mt. Lake Biological Station is located in USDA plant hardiness zones $5 \mathrm{~b}$ and 6a, Fishburn Experimental Forest is in zone 6a, and Twin Falls State Park lies in zones 6a and 6b (USDA, 2012).

\section{Hemlock health evaluation and sampling}

Thirty-two hemlock trees exhibiting symptoms of decline were selected for sampling each year. The trees selected for the 2011-2012 field study had a DBH (diameter at breast height) range of $4.5-22.1 \mathrm{~cm}$ with a mean of $11.8 \mathrm{~cm}$. Trees selected for the 2012-2013 field study had a mean DBH of $10.5 \mathrm{~cm}$ (range 4.8$21.8 \mathrm{~cm}$ ). Most of the hemlocks sampled showed typical signs of adelgid infestation, (i.e., needle loss and some bare branches), but also contained some healthy branches with new growth and moderate levels of adelgid populations.

Individual tree health was evaluated qualitatively by visually examining the entire tree for the percentage of 5 parameters: foliage (crown) density, live crown, live branches, live tips, and new foliage. The parameters were individually rated on a scale of $0-100 \%$ in $5 \%$ 
increments in a manner such that a high or low value would indicate a healthy or unhealthy condition, respectively. Percent foliage density was an estimate of the remaining foliage on the tree, which included recently defoliated branches, but not dead branches and the trunk. Percent live crown ratio was determined by estimating the ratio of the vertical length of the tree that supported live foliage relative to the total tree length (Schomaker et al., 2007). Percent live branches were determined by estimating the number of branches supporting live needles throughout the tree. Percent live branch tips were determined by estimating the hemlock branch tips for live foliage throughout the tree. Percent new growth was determined by estimating the amount of new growth present on the branch tips relative to the live and dead branch tips. New growth that developed during the current year was distinguished from old needle growth by twig and needle color and intact bud scales.

When branches were within reach from the ground, the terminal $1 \mathrm{~m}$ of two branches from each ordinal direction were examined and the number of branch tips with live needles and no needles (dead tip) and percent new growth was determined. If branches were not within reach, percent live tips and new growth were estimated by standing at the edge of the crown and examining the perimeter of the live crown. The mean of the 5 parameters was calculated to derive a Hemlock Health Index (0-100) similar to the Crown Condition Rating Guide used for Forest Health Monitoring assessments of forest stands by the USDA Forest Service (Millers et al., 1992; McAvoy, personal communication). A high index value indicates a healthy condition and a low index indicates an unhealthy condition. Samples taken for $A$. tsugae analysis, which were cut from $3 \mathrm{~m}$ (low-canopy) to $5 \mathrm{~m}$ (mid-canopy) above the ground with a pole pruner, were also examined to determine live tip and new growth values.

To evaluate hemlock health quantitatively, new shoot growth was measured $(\mathrm{cm})$. The beginning of a field season was dependent on $A$. tsugae sistens breaking aestivation. Both qualitative and quantitative hemlock health parameters were taken once per field season-in December 2011 and October 2012. Monthly cuttings throughout the low- and mid-canopy (December 2011 to April 2012 and December 2012 to April 2013) were obtained from each tree for $A$. tsugae analysis. These sample cuttings were placed in labeled self-sealing plastic bags and transported from the field in a cooler containing several ice packs. The samples were stored at $\approx 4{ }^{\circ} \mathrm{C}$ in a cold room until hemlock measurements and $A$. tsugae counts and collections could be performed.

\section{Adelges tsugae population assessments}

Adelges tsugae density and percent survival from aestivation were determined at the beginning of each field season (December 2011 and October 2012). Population density was calculated by counting the total adelgids on both low- and mid-canopy shoots $(25 \mathrm{~cm}$ of previous and $25 \mathrm{~cm}$ of new shoot growth). Survival of $A$. tsugae from aestivation was calculated in a manner similar to density by counting the number of settled individuals from which wax production was observed. Adelges tsugae density and survival were divided by 25 to determine the number of adelgids per centimeter of hemlock growth inclusive of all growth and canopy types.

Bimonthly sampling (21 February; 12-13 March; 2931 March; 14-16 April; 28-30 April in 2012 and 14-15 February; 4-5 March; 20-21 March; 2 April; 17 April; 6 May in 2013) was conducted to determine peak mean adelgid fecundity. To count the eggs per ovisac, an individual ovisac was removed from hemlock new growth (in the absence of ovisacs on new growth, ovisacs were obtained from old growth). Seventy percent ethanol was dripped onto the ovisac and the surrounding wax was teased away using probes under a dissection microscope (SMZ800 Nikon Instruments, Melville, NY, USA). Mean fecundity (mean eggs per ovisac) on each tree for each sample period was calculated by counting the eggs and chorions (the newly hatched crawlers) from 20 ovisacs (McClure, 1991b). Peak mean fecundity for each tree was determined to be the sampling period during which the maximum number of eggs was observed. This measure provides an estimate of fecundity since egg laying by the female continues even after eggs begin hatching.

Insect sample preparation Three samples of $\approx 30 \mathrm{~A}$. tsugae each were removed per hemlock from new foliage. The majority of the wax covering was removed from the insects by manipulation with probes under a dissecting microscope, and insects were collected using a microaspiration system with a vacuum pump. Fifteen insects of each sample were obtained from low-canopy foliage and the other fifteen from mid-canopy foliage to reduce any variability due to canopy level. The wet weight of each sample was obtained using a microbalance (Orion Cahn C-36, Thermo Scientific, Waltham, MA, USA). Samples destined for elemental analysis were frozen at $-16{ }^{\circ} \mathrm{C}$ until analysis. Remaining samples were homogenized in $30 \mu \mathrm{L} 70 \% \mathrm{EtOH}$ in a preweighed microcentrifuge tube. The homogenates were sonicated for 2-3 min (Solid State/Ultrasonic FS-28, Fisher Scientific, Leicestershire, UK), heated to $\approx 80{ }^{\circ} \mathrm{C}$ in a water bath, 
centrifuged for 5 min between 1050 and $1300 \mathrm{r} / \mathrm{m}$ with a 12-place rotor (Micro-Centrifuge Model 59A, Fisher Scientific), and stored at $-16{ }^{\circ} \mathrm{C}$ until use in the amino nitrogen and total carbohydrate assays.

Elemental analysis Each sample was dried at $78-83{ }^{\circ} \mathrm{C}$ overnight in the presence of absorbent silica beads. The dry weight $(\mathrm{mg})$ of each adelgid sample was obtained. A series of BSA and uric acid standards (SigmaAldrich, St. Louis, MD, USA and Sigma Chemical Company, St. Louis, MD, USA, respectively) were prepared for each group of $30 \mathrm{~A}$. tsugae samples. The standards and dried $A$. tsugae samples were placed in individual aluminum or silver capsules (Elementar, Germany) and elemental analysis was carried out with a vario EL Cube (Elementar, Germany) to determine the percent carbon and nitrogen content of each sample.

Amino nitrogen assay The ninhydrin assay was modified from Starcher (2001) and utilized to calculate total amino nitrogen in the $A$. tsugae tissue homogenates (McMurry, 2008). Ninhydrin reagent (MP Biomedicals, LLC, Solon, OH, USA) was prepared the day prior to running the assay according to Starcher (2001) at $19.5 \mathrm{mg} / \mathrm{mL}$. Dilutions of a $2 \mathrm{mg} / \mathrm{mL}\left(\mathrm{DI} \mathrm{H}_{2} \mathrm{O}\right.$ ) L-leucine stock solution was prepared as a standard curve (Nutritional Biochemicals Corporation, Cleveland, OH, USA).

The samples of adelgid homogenate were reconstituted to the original volume in $70 \% \mathrm{EtOH}$, vortexed, and centrifuged for $5 \mathrm{~min}$ at $\approx 3000 \mathrm{r} / \mathrm{m}$ to obtain a well-defined supernatant/pellet separation. Assays were run on 96-well polypropylene microplates (Thermo Fisher Scientific) or $0.2 \mathrm{~mL}$ 96-polypropylene PCR plates (TempPlate, USA Scientific, Orlando, FL, USA) and were covered with adhesive PCR film or well caps to reduce sample evaporation.

Each reaction contained $100 \mu \mathrm{L}$ ninhydrin reagent and either $10 \mu \mathrm{L} \mathrm{DI} \mathrm{H}_{2} \mathrm{O}$ as a control, $10 \mu \mathrm{L}$ of each standard, or $5 \mu \mathrm{L}$ sample $A$. tsugae homogenate plus $5 \mu \mathrm{L}$ DI $\mathrm{H}_{2} \mathrm{O}$ for a total volume of $110 \mu \mathrm{L}$ per well. All plates were heated in a $100{ }^{\circ} \mathrm{C}$ digital dry bath (GeneMate, BioExpress, Kaysville, UT, USA) for 20 min. Plates with PCR film were spun in a mini plate spinner (Labnet, Edison, NJ, USA) for $\approx 1$ min or shaken and tapped to mix in any accumulated condensation. The optical density of an aliquot of $80 \mu \mathrm{L}$ per reaction was read at $570 \mathrm{~nm}(\mathrm{M} 2$ SpectraMax, Molecular Devices, Sunnyvale, CA, USA).

Total carbohydrate assay The total carbohydrate assay was modified from van Handel and Day (1988). Anthrone reagent was prepared according to van Handel and Day (1988) at $1.4 \mathrm{mg} / \mathrm{mL}$. A standard curve was prepared from dilutions of a $2 \mathrm{mg} / \mathrm{mL}\left(\mathrm{DI} \mathrm{H}_{2} \mathrm{O}\right) \mathrm{D}(+)$-glucose stock solution. Both chemicals were obtained from Acros Organics (Morris Plains, NJ, USA).

Frozen A. tsugae samples were reconstituted in the same manner as the amino nitrogen assay. For carbohydrate separation from the A. tsugae homogenate, $100 \mu \mathrm{L}$ of a $1: 1$ chloroform : methanol solution and $75 \mu \mathrm{L} \mathrm{DI} \mathrm{H}_{2} \mathrm{O}$ were added to each sample homogenate. Each 96-well polypropylene PCR plate contained reactions of $175 \mu \mathrm{L}$ anthrone reagent and either $25 \mu \mathrm{L} \mathrm{DI} \mathrm{H}_{2} \mathrm{O}$ as a control, $25 \mu \mathrm{L}$ of each glucose standard, or $10 \mu \mathrm{L}$ sample $A$. tsugae carbohydrate homogenate plus $15 \mu \mathrm{L} \mathrm{DI} \mathrm{H}_{2} \mathrm{O}$ for a total volume of $200 \mu \mathrm{L}$ per reaction. Caps were sealed over each well to reduce evaporation, and the plates were nested on a $100{ }^{\circ} \mathrm{C}$ dry heat bath for $30 \mathrm{~min}$, cooled for 1-2 min and flipped and shaken to mix in condensation which may have accumulated on the caps. The optical density of an aliquot of $150 \mu \mathrm{L}$ from the reaction was read at $625 \mathrm{~nm}$.

\section{Statistical analysis}

A cluster analysis was carried out using Ward's hierarchical method combined with researcher judgment to group sample trees into 2 hemlock health categories based on hemlock new shoot growth and the Hemlock Health Index (Hair et al., 2010; Ward et al., 2010). Data collected on sample trees at all sites in both years were pooled for analysis. The distinctiveness of the cluster from the initial analysis was determined using a series of one-way ANOVAs to test for significant differences between the clusters with respect to each of the clustering variables (i.e., hemlock new shoot growth and the Hemlock Health Index) (Hair et al., 2010). The stability of the clusters was assessed by changes in the ordering of the data and using a nonhierarchical K-means clustering approach (Hair et al., 2010).

During both years, several of the trees were not infested by $A$. tsugae at a sufficiently high level for sampling. These trees were removed from further analysis, which reduced the sample size from 32 to 28 trees during 20112012 season and from 32 to 30 trees during 2012-2013 season. Sample size was further reduced because $A$. tsugae sampling for the physiological assays was not conducted during October and November 2011.

Multivariate analysis of variance (MANOVA) was used to study the relationship between the hemlock health categories generated by the cluster analysis and A. tsugae population health response variables (i.e., density, percent survival and peak fecundity). Following a significant MANOVA, a post hoc analysis with ANOVA was used to determine which of the three A. tsugae population health variables was responsible 
for the significant difference between the hemlock health categories (Scheiner, 2001; Hair et al., 2010).

Separate analyses were carried out using a mixed model for repeated measures ANOVA with a first-order autoregressive covariance structure to compare differences in the A. tsugae physiology on lightly and moderately impacted hemlocks over time with respect to biomass, total carbon, carbohydrate, total nitrogen, and amino nitrogen (Preisser \& Elkinton, 2008; Chaves, 2010). For each analysis, tree health category and month of sampling were the fixed-effect factors, and sampled trees nested within health category was the random factor. The month and tree were the repeated and subject parameters, respectively, of the autoregressive structure (Littell et al., 1996; Preisser \& Elkinton, 2008). Prior to each of the analyses, the response variable was tested for normality and, where necessary, was $\log 10(Y+1)$-transformed. The goodnessof-fit of the response variable to the normal distribution was determined based on the Shapiro-Wilk $W$ test statistic and/or by the skewness and kurtosis values (Thode, 2002; Zar, 2010). All statistical analyses were carried out using JMP Pro 11.0.0 (SAS, 2013) at a significance level of $\alpha=0.05$.

\section{Results}

\section{Hemlock health}

The various measurements for the Hemlock Health Index and new shoot growth indicated that the trees selected for sampling came from a relatively narrow range of hemlock health (Table 1). The cluster analysis on the variables resulted in two tree health categories, which were designated as "lightly impacted" and "moderately impacted" from A. tsugae based on our knowledge of the system. The analysis showed that the two health categories differed significantly with respect to both mean Health In$\operatorname{dex}(F=44.58 ; \mathrm{df}=1,58 ; P<0.0001)$ and mean new shoot growth $(F=96.11 ; \mathrm{df}=1,58 ; P<0.0001$; Table 1$)$, which suggested that the categories were statistically distinct. Lightly impacted trees are analogous to trees that would normally fall within the Crown Condition Rating Guide Class 1 (Good), whereas moderately impacted trees are analogous to those within Class 2 (Average) (Millers et al., 1992).

\section{Hemlock health and A. tsugae population health}

The MANOVA results showed that there was a significant difference between hemlock health categories with respect to the three $A$. tsugae population response vari-
Table 1 Comparison of the hemlock health measurements and new shoot growth for Adelges tsugae on lightly and moderately impacted hemlock trees combined from the 2011-2012 and 2012-2013 sampling periods.

\begin{tabular}{lcc}
\hline \multirow{2}{*}{$\begin{array}{c}\text { Tree health } \\
\text { measurement }\end{array}$} & \multicolumn{2}{c}{ Hemlock tree health categories ${ }^{\dagger}$} \\
\cline { 2 - 3 } & $\begin{array}{c}\text { Lightly impacted } \\
\text { trees (mean } \pm \mathrm{SE} \text { ) }\end{array}$ & $\begin{array}{c}\text { Moderately impacted } \\
\text { trees (mean } \pm \mathrm{SE} \text { ) }\end{array}$ \\
\hline \% Live crown ratio & $83.2 \pm 1.7$ & $76.3 \pm 1.5$ \\
\% Live branches & $79.8 \pm 1.8$ & $68.5 \pm 1.8$ \\
\% Tips alive & $82.8 \pm 1.6$ & $70.3 \pm 1.6$ \\
\% New foliage & $77.6 \pm 1.6$ & $62.1 \pm 1.8$ \\
\% Crown density & $78.7 \pm 1.5$ & $64.7 \pm 1.9$ \\
Health index & $80.4 \pm 1.3 \mathrm{a}$ & $68.4 \pm 1.4 \mathrm{~b}$ \\
New shoot growth & $5.3 \pm 0.3 \mathrm{a}$ & $2.2 \pm 0.1 \mathrm{~b}$ \\
(cm) & & \\
\hline
\end{tabular}

${ }^{\dagger}$ Cluster analysis of the health index and new shoot growth $(\mathrm{cm})$ variables categorized the sampled trees into 2 significantly different tree health categories JMP Pro 10.0.0 (SAS, 2013).

${ }^{\ddagger}$ The health index is the mean $\pm \mathrm{SE}$ of all 5 health measurements (\%) for each tree.

ables: density, percent survival from aestivation, and peak fecundity. Post hoc analysis showed that the significant difference was mainly as a result of mean peak fecundity (Fig. 1). The overall mean $A$. tsugae density was $15.66 \pm$ 1.04 individuals per centimeter of new growth. The overall mean A. tsugae percent survival from aestivation was $40.10 \pm 2.94$ individuals per centimeter of new growth. Adelges tsugae adult sistens laid significantly more eggs on moderately impacted trees than adults on lightly impacted trees. Mean peak fecundity was $67.72 \%$ greater on moderately impacted than on lightly impacted trees.

\section{Hemlock health and A. tsugaephysiological health}

A generally increasing, but significantly different trend (treatment $\times$ time) was observed for all $A$. tsugae physiological parameters on both lightly and moderately impacted hemlock trees (biomass: $F=28.08$; $\mathrm{df}=1167.7$; $P<0.0001$; carbon: $F=21.10 ; \mathrm{df}=1164.2 ; P<0.0001$; carbohydrate: $F=44.99$; df $=1161.3 ; P<0.0001$; nitrogen: $F=21.52 ; \mathrm{df}=1165.9 ; P<0.0001$; and amino nitrogen: $F=25.88$; df $=1168.3 ; P<0.0001)$. Overall, the lowest levels of the A. tsugae physiological parameters were obtained in December and January on both lightly and moderately impacted trees, while peak levels were observed in March and April on lightly and moderately impacted trees, respectively (Fig. 2). Throughout 


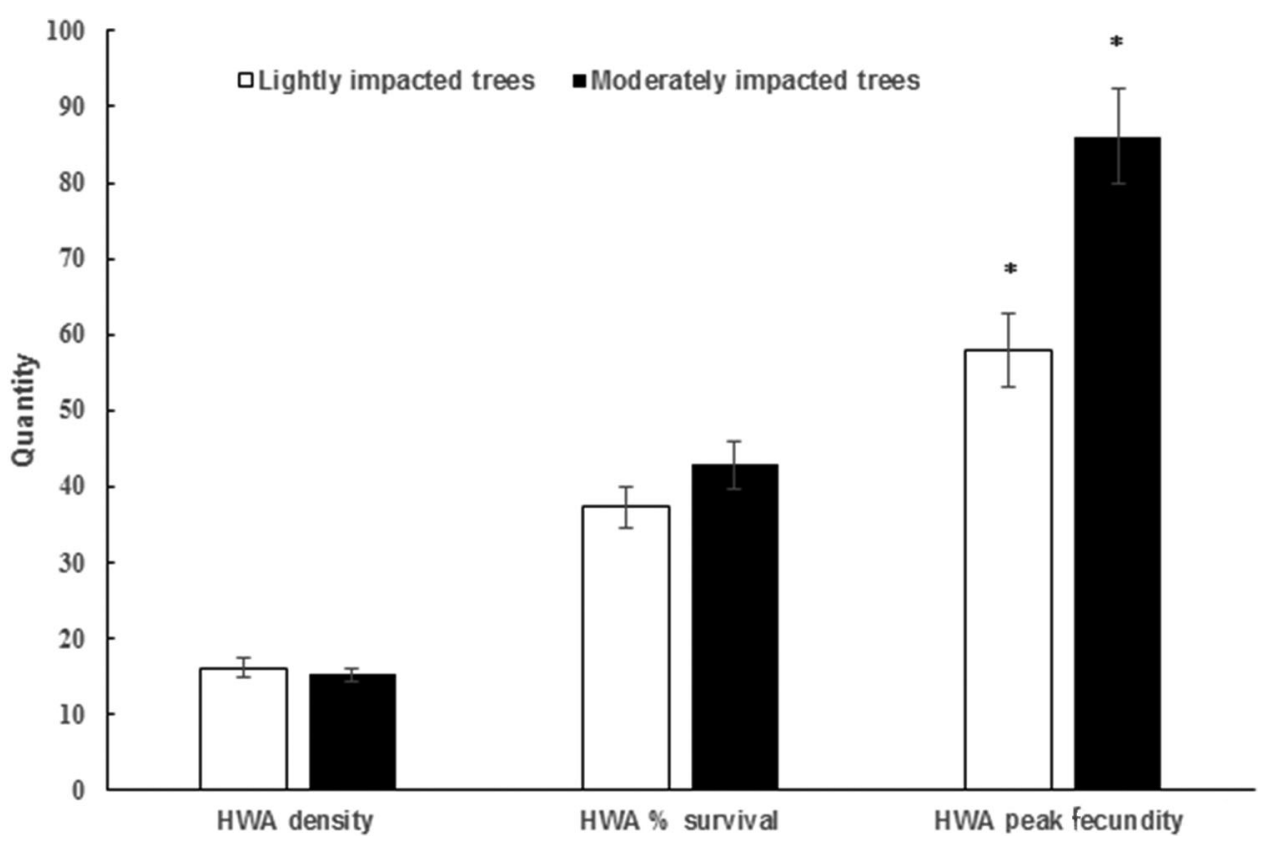

Fig. 1 Comparison of mean $\pm \mathrm{SE}$ A. tsugae density per centimeter branchlet, percent survival from aestivation per cm branchlet, and peak mean eggs per ovisac on lightly and moderately impacted hemlock trees. The asterisks $\left(^{*}\right)$ on $A$. tsugae fecundity indicate a significant difference between this measurement on lightly and moderately impacted hemlocks based on post hoc ANOVA analysis $(P<0.05)$ using JMP Pro 11.0.0 (SAS, 2013).

the sample period, insects from moderately impacted trees contained the same, or significantly lower levels of measured physiological components. However, biomass, total carbon, and total nitrogen in March were significantly greater in insects from moderately impacted trees than the insects on lightly impacted trees.

\section{Discussion}

This study employed quantitative and qualitative hemlock measurements to categorize hemlocks under two classifications as lightly and moderately impacted by $A$. tsugae. This allowed us to compare various aspects of $A$. tsugae health relative to the two described tree health categories. Although there are guidelines for assessing tree health, hemlock health determination is still fairly subjective (Millers et al., 1992). The hemlock trees with large $A$. tsugae populations examined throughout the study sites ranged from plentiful to meager foliage. Between the two extremes were many trees that exhibited moderately dense foliage and scattered $A$. tsugae populations throughout the tree canopy (McClure, 1991a). Finding a wider range of tree health was challenging since trees in a more severe state of decline do not generally support a population of adelgids necessary to make the measurements for this study.

It is known that individual hemlock trees can exhibit vastly different decline and A. tsugae population levels (McClure, 1991a; Eschtruth et al., 2013). Our tree health classification categorized the trees, not as broadly as "healthy" and "declining," but as lightly and moderately impacted by $A$. tsugae. Moderately impacted trees typically appeared to be in poorer health than lightly impacted trees. This difference in tree classification may better reflect the recolonization of trees by $A$. tsugae, but due to the limited tree variability may not allow for a full assessment of hemlock health impact on A. tsugae.

The measures of $A$. tsugae density and percent survival both represent the ability of $A$. tsugae sistens to successfully find suitable feeding sites and to break aestivation, respectively. Sussky and Elkinton (2014) report A. tsugae mortality from aestivation at $100 \%$ in a plantation setting and $16 \% \pm 2 \%$ in a forest setting in western MA. We report mean aestivation mortality at $40.10 \% \pm 2.93 \%$ in western VA and WV forests. Sistens survival from aestivation appears to be highly temperature dependent, necessarily affecting population dynamics throughout the range of A. tsugae (Sussky \& Elkinton, 2014).

Our results showed that sistens females had significantly greater peak mean fecundity on moderately 

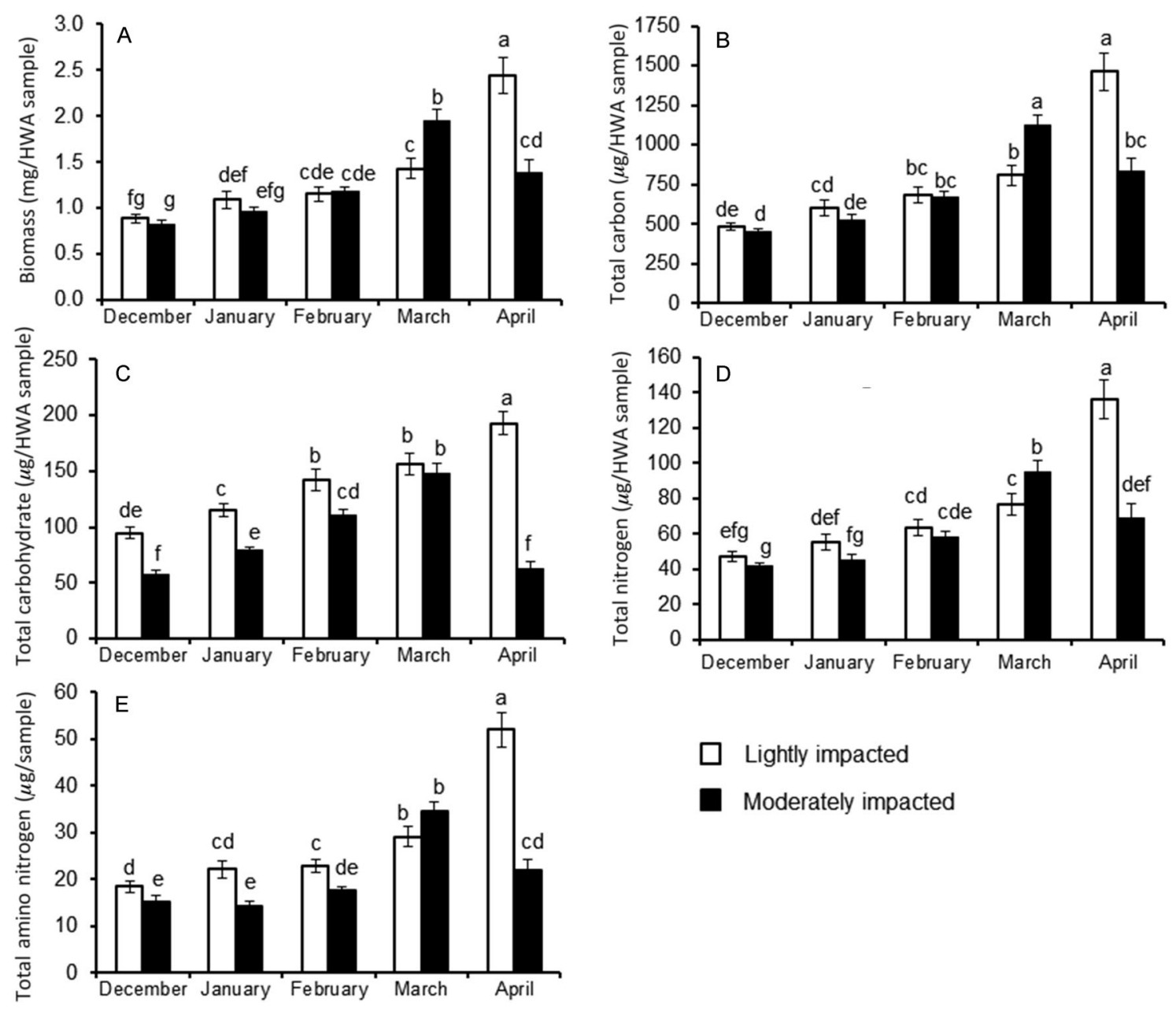

Lightly impacted

Moderately impacted

Fig. 2 Comparison between lightly and moderately impacted hemlocks (from 2011 to 2013) for mean \pm SE $A$. tsugae (A) biomass (mg/HWA sample), (B) total carbon ( $\mu \mathrm{g} / \mathrm{HWA}$ sample), (C) total carbohydrate ( $\mu \mathrm{g} / \mathrm{HWA}$ sample), (D) total nitrogen ( $\mu \mathrm{g} / \mathrm{HWA}$ sample), and $(\mathrm{E})$ total amino nitrogen $(\mu \mathrm{g} / \mathrm{HWA}$ sample) during the sistens generation. Total sampled trees, $n=57$. Letters indicate a significant difference based on a linear mixed model using JMP Pro 11.0.0 (SAS, 2013).

impacted trees than on lightly impacted trees, but their density and percent survival from aestivation did not differ between these health categories (Fig. 1). Greater sistens fecundity on moderately impacted trees may indicate an increase in the proportion of their eggs that hatch as winged sexuparae, in an ultimately futile effort to alternate between hemlock and the primary host, Picea spp. (McClure, 1991a). Initial studies examining the relationship between $A$. tsugae and hemlock have focused primarily on assessing adelgid health in terms of population density and fecundity (Broeckling \& Salom, 2003; Lagalante et al., 2006; Paradis, 2011). McClure (1991a) measured $A$. tsugae fecundity by counting the number of eggs and chorions from ovisacs with dead adults (indicating the termination of oviposition), and obtained fecundity measurements once, potentially missing the peak of $A$. tsugae fecundity on certain trees. Since adult A. tsugae lay eggs that hatch continually throughout the oviposition period, peak fecundity may provide a clearer fecundity assessment (McClure, 1987). The difference we observed in fecundity between moderately and lightly impacted trees is interesting in light of McClure's (1991a) findings that $A$. tsugae exhibits a higher rate of reproduction on healthy versus declining trees. This study reported A. tsugae peak fecundity at $57.89 \pm 4.74$ eggs per ovisac on lightly impacted trees and $86.14 \pm 6.17$ eggs per ovisac on moderately impacted trees. McClure (1991a) reported means of $121.5 \pm 19.6$ and $82.3 \pm 19.9$ eggs per ovisac on year old growth of previously uninfested and infested trees, respectively (adequate new growth on infested trees 
could not be obtained to make a comparison between treatments). Similarly Joseph et al. (2011) reported greater sistens fecundity on nitrogen-treated hemlocks than untreated trees. These studies suggest that better tree health likely supports healthier $A$. tsugae populations as represented by sistens fecundity, contrary to our findings. It should be noted, however, that hemlock infestation, location, and treatment were varied among this study and those of McClure (1991a) and Joseph et al. (2011), since our trees were naturally infested in a forest setting without fertilizer or insecticide treatment. It may be that A. tsugae density measurements do not provide a nuanced assessment of insect health and by association hemlock quality. The addition of mean peak fecundity can provide greater detail concerning the A. tsugae-hemlock dynamic.

Adelges tsugae fecundity may directly reflect the accessibility of hemlock nutrients to the growing sistens. Since hemlock tree health will dictate $A$. tsugae health (the assimilation of adequate nutrients for growth and reproduction) it is possible that increased nutrient flow in moderately impacted hemlocks provides the A. tsugae population sufficient nutrients for increased fecundity (McClure, 1991a; Eisenback et al., 2010). Alternatively A. tsugae from moderately impacted trees may be laying larger numbers of poor-quality eggs (Fig. 1). The significantly lower levels of carbohydrates, nitrogen, and amino nitrogen in insects collected from moderately impacted trees may indicate a lack of available nutrients in these trees, compared with their levels in lightly impacted trees. As is the case with all herbivores, $A$. tsugae may partially regulate the absorption and utilization of available nutrients, but will ultimately be affected by the health of its host (Behmer, 2009). Adelges tsugae appears to alter their assimilation (ingestion and storage) of nutrients during maturation in anticipation for egg production (Figs. 2D and E) (Brodbeck et al., 1990; Boggs, 1981).

All of the A. tsugae physiological parameters increased significantly over time as the insect matured and were highest during $A$. tsugae oogenesis and the oviposition of the progrediens generation (February to April) (Fig. 2). Typically plants respond to herbivore attack by mobilizing soluble nitrogen away from stressed tissues to nutrient sinks or secondary metabolite synthesis, allowing herbivores feeding on such tissues a ready supply of nitrogen in their food (White, 1974; White, 1984; Price, 1991). However, at times of high stress levels, the tree may become a limited nonresource to insects, either because it no longer provides the insect with adequate food sources or because it is dead (Larsson, 1989; Schwartzberg \& Montgomery, 2010; Radville et al., 2011). To ensure sufficient resources for her offspring, female insects on a poor-quality host plant may lay either a few good-quality eggs or a large number of poor-quality eggs. This manipulation of offspring quality may be related to nitrogen variability in the diet of the parent (Awmack \& Leather, 2002). Poor food availability or composition for the adult female may result in a reduced rate or quality of egg production (Slansky, 1982).

In the hemlock- $A$. tsugae system, trees treated with nitrogen fertilizer support an increased insect population, as well as nymph and egg survival, suggesting than nitrogen is a limited resource for A. tsugae (McClure, 1991b). While initial tree stress may encourage high $A$. tsugae densities, continual stress will cause negative effects on the herbivore population (McClure, 1991b; Cornelissen et al., 2008). It is possible that other physiological factors such as carbohydrate levels could have a similar relationship within this system. Nutrient assimilation is particularly important for sessile, specialist insects, such as $A$. tsugae, as they are limited to obtaining a balance of nutrients for optimum fitness from a narrow nutrient range (House, 1962; Slansky, 1982; Young et al., 1995; McClure \& Cheah, 2002; Raubenheimer \& Simpson, 2003; Hanife, 2006). Insect herbivores such as $A$. tsugae may utilize the carbohydrate storage in the xylem ray parenchyma of hemlock for energy, exoskeleton development, and egg production (Slansky, 1982; Mullins, 1985; Brodbeck et al., 1990; Young et al., 1995; Hanife, 2006; Behmer, 2009; Arrese \& Soulages, 2010). Nitrogen is essential for protein production and organism growth and reproduction (Slansky \& Rodriguez, 1987; Brodbeck et al., 1990; Slansky, 1990). Nitrogen fluctuations within the plant xylem, phloem, and other tissues, may therefore, affect nitrogen content in herbivorous insects (Slansky \& Rodriguez, 1987; Brodbeck et al., 1990; Fagan et al., 2002). Changes in body composition over time are associated with maturation as well as changes in food quality (House, 1962; Scriber \& Slansky, 1981; Hanife, 2006).

During this study, we performed the first analysis of $A$. tsugae physiological parameters spanning the sistens generation maturation period. These analyses will allow for the continued examination of $A$. tsugae health at a physiological level. All physiological parameters increased throughout the insect's lifespan with those from moderately impacted trees dropping after March and those from lightly impacted increasing into April. Since A. tsugae exhibited higher fecundity on moderately impacted trees despite having the same or lower physiological parameters it is evident that there is a more complex relationship between true health and insect performance than a simple direct relationship. Continued examination of progrediens egg hatch and development would provide information about $A$. tsugae maternal investment in the next generation. An examination of a wider range of tree health and 
a physiological assessment of the $A$. tsugae feeding sites on hemlock is needed to more thoroughly understand the relationship between hemlock health and A. tsugae health. This information will aid in determining when and where predator field releases may have the most effective establishment and in the selection of high-quality A. tsugae for predator colony food.

\section{Acknowledgments}

The authors would like to thank T. Anderson for use of lab space and equipment, A. Reeves for preliminary assay development, A. Tanner for expertise with elemental analysis, and the many individuals who assisted with sample collection and measurements. We appreciate the Fishburn Experimental Forest, the University of Virginia Biological Station at Mt. Lake, and Twin Falls State Park, WV for their cooperation in completing this research on their property. This research was supported by cooperative agreement \# 07-CA-11420004-161 between the United States Forest Service and Virginia Tech.

\section{Disclosure}

The authors of this manuscript report no conflicts of interest.

\section{References}

Arrese, E.L. and Soulages, J.L. (2010) Insect fat body: energy, metabolism, and regulation. Annual Review of Entomology, 55, 207-225.

Awmack, C.S. and Leather, S.R. (2002) Host plant quality and fecundity in herbivorous insects. Annual Review of Entomology, 47, 817-844.

Behmer, S.T. (2009) Insect herbivore nutrient regulation. Annual Review of Entomology, 54, 165-187.

Boggs, C.L. (1981) Nutritional and life-history determinants of resource allocation in holometabolous insects. The American Naturalist, 117, 692-709.

Brodbeck, B.V., Mizell, R.F.I., French, W.J., Andersen, P.C. and Aldrich, J.H. (1990) Amino acids as determinants of host preference for the xylem feeding leafhopper, Homalodisca coagulata (Homoptera: Cicadellidae). Oecologia, 83, 338345.

Broeckling, C.D. and Salom, S.M. (2003) Volatile emissions of eastern hemlock, Tsuga canadensis, and the influence of hemlock woolly adelgid. Phytochemistry, 62, 175-180.

Carter, C.I. (1971) Conifer woolly aphids (Adelgidae) in Britain. Forestry Commission Bulletin, 42, H.M.S.O.
Chaves, L.F. (2010) An entomologist guide to demystify pseudoreplication: data analysis of field studies with design constraints. Journal of Medical Entomology, 47, 291-298.

Cheah, C.A.S.J. and McClure, M.S. (2000) Seasonal synchrony of life cycles between the exotic predator, Pseudoscymnus tsugae (Coleoptera: Coccinellidae) and its prey, the hemlock woolly adelgid Adelges tsugae (Homoptera: Adelgidae). Agricultural and Forest Entomology, 2, 241-251.

Cornelissen, T., Fernandes, G.W. and Vasconcellos-Neto, J. (2008) Size does matter: variation in herbivory between and within plants and the plant vigor hypothesis. Oikos, 117, 1121-1130.

Eisenback, B.M., Salom, S.M., Kok, L.T. and Lagalante, A.F. (2010) Lethal and sublethal effects of imidacloprid on hemlock woolly adelgid (Hemiptera: Adelgidae) and two introduced predator species. Journal of Economic Entomology, 103, 1222-1234.

Eschtruth, A.K., Evans, R.A. and Battles, J.J. (2013) Patterns and predictors of survival in Tsuga canadensis populations infested by the exotic pest Adelges tsugae: 20 years of monitoring. Forest Ecology and Management, 305, 195-203.

Fagan, W.F., Siemann, E., Mitter, C., Denno, R.F., Huberty, A.F., Woods, H.A. and Elser, J.J. (2002) Nitrogen in insects: implications for trophic complexity and species diversification. The American Naturalist, 160, 784-802.

Fidgen, J.G., Legg, D.E. and Salo, S.M. (2006) Binomial sequential sampling plan for hemlock woolly adelgid (Hemiptera: Adelgidae) sistens infesting individual eastern hemlock trees. Journal of Economic Entomology, 99, 1500-1508.

Gómez, S., Orians, C. and Preisser, E. (2012) Exotic herbivores on a shared native host: tissue quality after individual, simultaneous, and sequential attack. Oecologia, 169, 10151024.

Hair, J.F.J., Black, W.C., Babin, B.J. and Anderson, R.E. (2010) Multivariate Data Analysis, Prentice Hall, NJ.

Hanife, G. (2006) General principles of insect nutritional ecology. Trakya University Journal of Science, 7, 53-57.

Havill, N.P. and Foottit, R.G. (2007) Biology and evolution of Adelgidae. Annual Review of Entomology, 52, 325-349.

Havill, N.P., Vieira, L.C. and Salom, S.M. (2014) Biology and Control of Hemlock Woolly Adelgid. USDA Forest Service, FHTET 2014-05.

House, H. (1962) Insect nutrition. Annual Review of Biochemistry, 31, 653-672.

Jenkins, J.C. (1999) Hemlock woolly adelgid impacts on community structure and $\mathrm{N}$ cycling rates in eastern hemlock forests. Canadian Journal of Forest Research, 29, 630-645.

Jones, A.C., Mullins, D.E., Jones, T.H. and Salom, S.M. (2014) Characterization of physical and chemical defenses in the hemlock woolly adelgid. Journal of Chemical Ecology, 40, $560-568$. 
Joseph, S.V., Hanula, J.L., Braman, S.K. and Byrne, F.J. (2011) Effects of fertilizer and low rates of inmidacloprid on Adelges tsugae (Hemiptera: Adelgidae). Journal of Economic Entomology, 104, 868-878.

Lagalante, A., Lewis, N., Montgomery, M. and Shields, K. (2006) Temporal and spatial variation of terpenoids in eastern hemlock (Tsuga canadensis) in relation to feeding by Adelges tsugae. Journal of Chemical Ecology, 32, 2389-2403.

Larsson, S. (1989) Stressful times for the plant stress: insect performance hypothesis. Oikos, 56, 277-283.

Lee, K.P. (2007) The interactive effects of protein quality and macronutrient imbalance on nutrient balancing in an insect herbivore. Journal of Experimental Biology, 210, 32363244.

Littell, R., Milliken, G., Stroup, W. and Wolfinger, R. (1996) SAS Systems for Mixed Models [Online]. Cary, NC: SAS Institute. 2014.

Mayer, M., Chianese, R., Scudder, T., White, J., Vongpaseuth, K. and Ward, R. (2002) Thirteen years of monitoring the hemlock woolly adelgid in New Jersey forests. Proceedings: Hemlock woolly adelgid in the Eastern United States Symposium (eds. B. Onken, R. Reardon \& J. Lashomb). Rutgers University East Brunswick, NJ.

McClure, M.S. (1980) Competition between exotic species: scale insects on hemlock. Ecology, 61, 1391-1401.

McClure, M.S. (1987) Biology and control of hemlock woolly adelgid, Connecticut Agricultural Experiment Station, Bulletin 851 .

McClure, M.S. (1989) Evidence of a polymorphic life cycle in the hemlock woolly adelgid, Adelges tsugae (Homoptera: Adelgidae). Annals of the Entomological Society of America, 82, 50-54.

McClure, M.S. (1991a) Density-dependent feedback and population cycles in Adelges tsugae (Homoptera: Adelgidae) on Tsuga canadensis. Environmental Entomology, 20, 258-264.

McClure, M.S. (1991b) Nitrogen fertilization of hemlock increases susceptibility to hemlock woolly adelgid. Journal of Arboriculture, 17, 227-230.

McClure, M.S. (1992) Hemlock woolly adelgid. American Nurseryman, 175, 82-89.

McClure, M.S. and Cheah, C.A.S.J. (2002) Important mortality factors in the life cycle of hemlock woolly adelgid Adelges tsugae Annand (Homoptera: Adelgidae) in the northeastern United States. Hemlock Woolly Adelgid in the Eastern United States Symposium (eds. R.C. Reardon, B.P. Onken \&J. Lashomb). New Brunswick, NJ: New Jersey Agricultural Experimental Station.

McMurry, J. (2008) Organic Chemistry, Belmont, CA, Thomson Higher Education.

Meloni, F., Lopes, N.P. and Varanda, E.M. (2012) The relationship between leaf nitrogen, nitrogen metabolites and herbivory in two species of Nyctaginaceae from the Brazilian
Cerrado. Environmental and Experimental Botany, 75, 268276.

Miller-Pierce, M.R., Orwig, D.A. and Preisser, E. (2010) Effects of hemlock woolly adelgid and elongate hemlock scale on eastern hemlock growth and foliar chemistry. Environmental Entomology, 39, 513-519.

Millers, I., Anderson, R., Burkman, W. and Hoffard, W. (1992) Forest health monitoring crown condition rating guide. USDA Forest Service, State and Private Forestry, Northeastern Area and Southern Region.

Mullins, D.E. (1985) Chemistry and physiology of the hemolymph. Comprehensive Insect Physiology, Biochemistry, and Pharmacology (eds. G.A. Kerkut \& L.I. Gilbert). New York: Pergamon Press.

Paradis, A.F. (2011) Population dynamics of the hemlock woolly adelgid (Hemiptera: Adelgidae). PhD Disertation, University of Massachusetts.

Preisser, E.L. and Elkinton, J.S. (2008) Exploitative competition between invasive herbivores benefits native host plant. Ecology, 89, 2671-2677.

Price, P.W. (1991) The plant vigor hypothesis and herbivore attack. Oikos, 62, 244-251.

Radville, L., Chaves, A. and Preisser, E. (2011) Variation in plant defense against insect herbivores: evidence for a hypersensitive response in eastern hemlocks (Tsuga canadensis). Journal of Chemical Ecology, 37, 592-597.

Raubenheimer, D. and Simpson, S. (2003) Nutrient balancing in grasshoppers: behavioural and physiological correlates of dietary breadth. Journal of Experimental Biology, 206, 16691681.

Rohfritsch, O. (1990) Aphid stylet movement and host-plant reaction in the case of Adelgidae on spruce. Aphid-Plant Genotype Interactions (eds. R. Campbell \& R. Eikenbary). New York, New York: Amsterdam: Elsevier.

SAS (2013) JMP Version 10.0.0 ed. SAS Institute, Cary, NC.

Scheiner, S.M. (2001) MANOVA: Multiple response variables and multispecies interactions. Design and Analysis of Ecological Experiments (eds. M. Scheiner \& J. Gurevitch). New York, USA: Oxford University Press.

Schomaker, M.E., Zarnock, S.J., Bechtold, W.A., Latelle, D.J., Burkman, W.G. and Cox, S.M. (2007) Crown-Condition Classification: A Guide to Data Collection and Analysis. USDA, Forest Service, Asheville, North Carolina: Southern Research Station.

Schwartzberg, L. and Montgomery, M.E. (2010) Relationships of nonstructural carbohydrates and the hemlock woolly adelgid. Fifth Symposium on Hemlock Woolly Adelgid in the Eastern United States (eds. B. Onken \&R. Reardon). USDA Forest Service, FHTET 2010-01.

Scriber, J. and Slansky Jr, F. (1981) The nutritional ecology of immature insects. Annual Review of Entomology, 26, 183211. 
Slansky, F. (1982) Insect nutrition: an adaptationist's perspective. Florida Entomologist, 65, 45-71.

Slansky, F. (1990) Insect nutritional ecology as a basis for studying host plant resistance. Florida Entomologist, 73, 359-378.

Slansky, F. and Rodriguez, J. (1987) Nutritional Ecology of Insects, Mites, Spiders, and Related Invertebrates, Wiley, New York

Stadler, B. (2006) The ecology of energy and nutrient fluxes in hemlock forests invaded by hemlock woolly adelgid. Ecology, 87, 1792-1804.

Stadler, B., Müller, T., Orwig, D. and Cobb, R. (2005) Hemlock woolly adelgid in New England forests: canopy impacts transforming ecosystem processes and landscapes. Ecosystems, 8, 233-247.

Starcher, B. (2001) A ninhydrin-based assay to quantitate the total protein content of tissue samples. Analytical Biochemistry, 292, 125-129.

Sussky, E. and Elkinton J.S. (2014) Density-dependent survival and fecundity of hemlock woolly adelgid (Hemiptera: Adelgidae). Environmental Entomology, 43, 1157-1167.

Thode, H.C.J. (2002) Testing for Normality. New York, USA, Marcel Dekker.

Tomlinson, S., Arnall, S.G., Munn, A., Bradshaw, S.D., Maloney, S.K., Dixon K.W. and Didham, R.K. (2014) Applications and implications of ecological energetics. Trends in Ecology \& Evolution, 29, 280-290.
USDA (2012) 2012 Plant Hardiness Zone Map [Online]. USDA Beltsville, MD: ARS. [Accessed August 26 2013].

vanHandel, E. and Day, J. (1988) Assay of lipids, glycogen and sugars in individual mosquitoes: correlations with wing length in field-collected Aedes vexans. Journal of the American Mosquito Control Association, 4, 549-550.

Ward, P.S., Brady, S.G., Fisher, B.L. and Schultz, T.R. (2010) Phylogeny and biogeography of dolichoderine ants: effects of data partitioning and relict taxa on historical inference. Systematic Biology, 59, 342-362.

White, T.C.R. (1974) A hypothesis to explain outbreaks of looper caterpillars, with special reference to populations of Selidosema suavis in a plantation of Pinus radiata in New Zealand. Oecologia, 16, 279-301.

White, T.C.R. (1984) The abundance of invertebrate herbivores in relation to the availability of nitrogen in stressed food plants. Oecologia, 63, 90-105.

Young, R.F., Shields, K.S. and Berlyn, G.P. (1995) Hemlock woolly adelgid (Homoptera: Adelgidae): stylet bundle insertion and feeding sites. Annals of the Entomological Society of America, 88, 827-835.

Zar, J.H. (2010) Biostatistical Analysis, New Jersey, USA, Prentice Hall.

Accepted April 22, 2015 